Notre Dame Law School

NDLScholarship

Journal Articles

Publications

2002

\title{
An Introduction to the Federal Constitutional Court
}

Donald P. Kommers

Notre Dame Law School, donald.p.kommers.1@nd.edu

Follow this and additional works at: https://scholarship.law.nd.edu/law_faculty_scholarship

Part of the Comparative and Foreign Law Commons, and the Constitutional Law Commons

\section{Recommended Citation}

Donald P. Kommers, An Introduction to the Federal Constitutional Court, 2 German L. J. 1 (2002).

Available at: https://scholarship.law.nd.edu/law_faculty_scholarship/1378

This Article is brought to you for free and open access by the Publications at NDLScholarship. It has been accepted for inclusion in Journal Articles by an authorized administrator of NDLScholarship. For more information, please contact lawdr@nd.edu. 


\section{An Introduction to the Federal Constitutional Court}

By Donald P. Kommers

Suggested Citation: Donald P. Kommers, An Introduction to the Federal Constitutional Court, 2 German Law Journal (2001), available at http://www.germanlawjournal.com/index.php?pagelD=11\&artID=19

A. Introduction [1] If social and political stability in a democratic state requires effective constitutional review, the brutal instability of German society over the first half of the 20th Century testifies to the shortcomings of earlier manifestations of German constitutionalism and the mechanisms for constitutional review upon which those constitutional systems relied. By the same standard, however, the stability and prosperity West Germany enjoyed (and has continued to enjoy since October 1990, as a reunified Germany) over the last half of the 20th Century bespeaks the integrity and efficacy of the Bundesverfassungsgericht (Federal Constitutional Court), the unique constitutional organ celebrating its 50th anniversary this year. [2] This essay introduces the Federal Constitutional Court, briefly surveying the Court's legal heritage, the history of its founding, its jurisdiction, and its structure. B. Legal Heritage of the Federal Constitutional Court [3] The Federal Constitutional Court, as a mechanism of constitutional review, is based on the model championed by the Austrian legal scholar Hans Kelsen (variably referred to as the Kelsen, Austrian or Continental model). First formally outlined in the early inter-war period, Kelsen's model distinguished itself from the British/Commonwealth and American models of constitutional review that dominated at the time. Kelsen's significant innovations and distinctions included: (a) the specialization of constitutional review, to be handled by distinct constitutional courts or special chambers of the highest appellate court; and (b) recognition of the political nature of constitutional review by, inter alia, making judicial appointments more overtly political. [4] One factor that encouraged the framers of the Grundgesetz (Basic Law) to adopt the Kelsen model and assign the function of constitutional review to a single court was the traditional structure of the German judiciary and the unfamiliarity of its judges with constitutional adjudication. The German judiciary includes separate hierarchies of administrative, labor, fiscal, and social courts, while ordinary civil and criminal jurisdiction is vested in another, much larger, system of regular courts. All trial and intermediate courts of appeal are Land (federal state) tribunals; federal courts serve as courts of last resort. Like the appellate courts generally, these tribunals are staffed by a host of judges who sit in panels of five. The complexity of this structure and the lack of any tradition of stare decisis would have rendered an American-style decentralized system of judicial review, in which all courts may declare laws unconstitutional, unworkable in Germany. [5] Variations on Kelsen's model now constitute a majority of the world's institutions exercising constitutional review, including the constitutional courts (or constitutional chamber of the supreme courts) of more than 70 nations. (2) C. The Founding of the Federal Constitutional Court [6] The nature and structure of the new constitutional court was extensively debated at the West German constitutional convention (i.e., the Parliamentary Council). Meeting in 1948-1949, the Parliamentary Council generated the text that functions as the German constitution, known as the Grundgesetz (Basic Law). In outlining the institutional infrastructure of the new Federal Republic, the Basic Law provided for a Federal Constitutional Court. The debate in the Parliamentary Council over constitutional review boiled down to a dispute over whether the new constitutional institution should be like Weimar's Staatsgerichtshof (State Court) and serve mainly as an organ for resolving conflicts between branches and levels of government (i.e., a court of constitutional review), or whether it should combine such jurisdiction with the general power to review the constitutionality of legislation (i.e., judicial review)? The framers finally agreed to create a constitutional tribunal independent of other public-law courts, but they disagreed over how much of the constitutional jurisdiction listed in the proposed constitution should be conferred on the court as opposed to other high federal courts. [7] The controversy over the scope of the Federal Constitutional Court's jurisdiction centered on the distinction between what some delegates regarded as the "political" role of a constitutional court and what others considered to be the more "objective" law-interpreting role of the regular judiciary. Some delegates preferred two separate courts one to review the constitutionality of laws (i.e., judicial review), the other to decide essentially political disputes among branches and levels of government (i.e., constitutional review). Others favored one grand, multipurpose tribunal divided into several panels, each specializing in a particular area of public or constitutional law. This proposal was strenuously opposed by many German judges who were alarmed by any such mixing of law and politics in a single institution. The upshot was a compromise resulting in a separate constitutional tribunal with exclusive jurisdiction over all constitutional disputes, including the authority to review the constitutionality of laws. [8] The two main parties in the Parliamentary Council favored limited rules of access to the new constitutional court, the Social Democrats because they would protect political minorities in and out of parliament, and the Christian Democrats because they saw the rules as equally useful in preserving German federalism. [9] The interests of both political parties were also reflected in the judicial selection clauses specifying that the Federal Constitutional Court shall consist of "federal judges and other members," half "to be elected by the Bundestag and half by the Bundesrat" (Article 94). Christian Democrats were thus assured of a strong "federal" presence on the court, just as Social Democrats could take comfort in knowing that the court would not be dominated by professional judges drawn wholly from a conservative judiciary. The remaining details of the court's organization and procedure were left to later legislation. [10] Almost two additional years of debate were necessary to produce the enabling statute creating the Federal Constitutional Court. The shape of the new tribunal represented a compromise between conflicting perspectives of the federal government, the Social Democrats, and the Bundesrat on such matters as judicial selection and tenure, the ratio of career judges to "other members," the qualifications of judicial nominees, the court's size and structure, and the degree of control 
over the court to be exercised by the Federal Ministry of Justice. All participants in the debate recognized that the court's political acceptance would depend on broad agreement on these matters across party and institutional lines. Finally, after months of intensive negotiation within and between the Bundestag and the Bundesrat, a bill emerged with the overwhelming support of the major parliamentary parties and all branches of government. The result was the Federal Constitutional Court Act (Bundesverfassungsgerichtsgesetz) of March 12, 1951. D. The Jurisdiction of the Federal Constitutional Court [11] The Basic Law extends the court's jurisdiction to twelve categories of disputes and "such other cases as are assigned to it by federal legislation" (Article 93[2]). Originally, the court's jurisdiction could only be invoked by federal and state governments (i.e., the chancellor or minister-president and his or her cabinet), parliamentary political parties, and, in certain circumstances, courts of law. The constitution's framers rejected the proposal to confer on private parties the constitutional right to petition the court, a decision in line with the general practice of constitutional review in Weimar Germany and Austria. An individual right to petition the constitutional court was created by statute in 1951, and was incorporated into the Basic Law in 1969 (Art. 93(1)[4a]). [12] The Constitutional Court's jurisdiction, established by the constitution itself, includes: Forfeiture of basic rights (Article 1) Constitutionality of political parties (Article 21[2]) Review of election results (Article 41[2]) Impeachment of the federal president (Article 61) Disputes between high state organs (Article 93[1]) Abstract judicial review (Article 93[1]) Federal-state conflicts (Articles 93[1] and 84[4]) Concrete judicial review (Article 100[1]) Removal of judges (Article 98) Intrastate constitutional disputes (Article 99) Public international law actions (Article 100[2]) State constitutional court references (Article 100[3]) Applicability of federal law (Article 126) Constitutional complaints (Article 93[1]) [13] Of the Court's various competences, the constitutional complaint is the most frequently invoked and the most visible. A former President of the Federal Constitutional Court once remarked that the "administration of justice in the Federal Republic of Germany would be unthinkable without the complaint of unconstitutionality." (3) According to Article 93(1)[4a] of the Basic Law, any person may enter a complaint of unconstitutionality if one of his or her fundamental substantive or procedural rights under the constitution has been violated by "public authority," including judicial decisions, administrative decrees and legislative acts. Before filing a constitutional complaint, all other available means to find relief in the ordinary courts must be exhausted. Constitutional complaints must be lodged within a certain time, identifying the offending actions or omission and the agency responsible. The complaint must also specify the constitutional right that has been violated. The Federal Constitutional Court Act requires the court to accept any complaint if it is constitutionally significant or if the failure to accept it would work a grave hardship on the complaint. The procedure for filing complaints in the Constitutional Court is relatively easy and inexpensive. No filing fees or formal papers are required. Most complaints are handwritten and prepared without the aid of a lawyer. No legal assistance is required at any stage of the complaint proceeding. As a consequence of these rather permissive "standing" rules, the court has been flooded with complaints - from 452 in the Court's first year to well over 5,000 in the last years. (4) E. Structure, Procedure and Membership [14] The Federal Constitutional Court Act codifies and fleshes out the Basic Law's provisions relating to the court's organization, powers, and procedures. Representing numerous political compromises, the Act, inter alia, (1) lays down the qualifications (5) and tenure (6) of the court's members; (2) specifies the procedures of judicial selection; (7) (3) provides for the two, eight-judge Senates; (8) and (4) enumerates the jurisdiction of each senate. (9) [15] The most important structural feature of the Constitutional Court is its division into two, eight-judge Senates with mutually exclusive jurisdiction and personnel. Jurisdiction over constitutional complaints and the judicial review of laws is shared by the two Senates. In all other proceedings the Second Senate has exclusive jurisdiction. [16] The judges of each Senate are assigned to the Senate's three Chambers, each of which is staffed by three judges. The Court's President (currently a member of the Second Senate) and Vice-President (currently a member of the First Senate) participate in the work of two of their Senate's Chambers. The Chambers primarily determine whether a constitutional complaint is to be accepted for adjudication. A Chamber may dismiss a complaint if all three of its members consider it to be "inadmissible or to offer no prospect of success for other reasons." If one of the three judges votes to accept the complaint, the case is then registered with the full Senate. The Chambers may also rule on the merits of a constitutional complaint if all three judges agree with the result and the decision clearly lies within standards already laid down in a case decided by the full Senate. The Chambers dispose of $95 \%$ of all complaints, relieving the Senates of what would otherwise be an impossible task. [17] In its fifty-year history, 90 judges have served at the Federal Constitutional Court, including eight women. A list of the judges of the Federal Constitutional Court follows in the Annex to this Article. F. Conclusion [18] Owing to its record in defending the principles of democracy and constitutionalism, not to mention the volume and sophistication of its jurisprudence, the Federal Constitutional Court has blossomed into one of the world's most prestigious constitutional tribunals. The Court has served as a leading model for the creation of judicial review in the new democracies of Eastern Europe as well as in many other countries around the world. In addition, national courts of constitutional review routinely consult its decisions when deciding cases and disputes under their respective national constitutions. In short, the Federal Constitutional Court's influence around the globe is now fully the equal, if not more so, to that of the United States Supreme Court. http://www.dukeupress.edu/books/index.shtml">Go to Professor Kommers' Authoritative Book on German Constitutionalism: The Constitutional Jurisprudence of the Federal Republic of Germany (Duke University Press) http://www.amazon.com/exec/obidos/ASIN/0822318385/o/qid\%3D991259787/sr\%3D2-2/103-1954250-4959869">Go to Professor Kommers' Authoritative Book on German Constitutionalism: The Constitutional Jurisprudence of the Federal Republic of Germany (Amazon.com) Annex -- List of the Judges of the Federal Constitutional Court (10) 
First Senate I. Elected by the Bundestag's Judicial Selection Committee Seat; Position 1.1 Höpker-Aschoff, Hermann (1951-1954) President 1.2 Wintrich, Josef (1954-1958) President 1.3 Müller, Gebhard (1959-1971) President 1.4 Benda, Ernst (1971-1983) President 1.5 Herzog, Roman (1984-1987) Vice President by Bundesrat (1987-1995) President 1.6 Hass, Evelyn \{1994 -- $\}$ Justice 2.1 Zweigert, Kurt (1951-1952) Justice 2.2 Heck, Karl (1954-1964) Justice 2.3 Böhmer, Werner (1965-1983) Justice 2.4 Neidermaier, Franz (1983-1986) Justice 2.5 Seidl, Otto (19861998) Justice 2.6 Papier, Hans-Jürgen \{1998 -- $\}$ Justice by Bundesrat \{1998 -- $\}$ Vice President 3.1 Heiland, Gerhard (1951-1961) Justice 3.2 Haager, Karl (1962-1979) Justice 3.3 Heußner, Hermann (1979-1989) Justice 3.4 Kühling, Jürgen (1989-2001) Justice 3.5 Bryde, Brun-Otto \{2001 -- \} Justice 4.1 Scholtissek, Herbert (1951-1967) Justice 4.2 Brox, Hans (1967-1975) Justice 4.3 Katzenstein, Dietrich (1975-1987) Justice 4.4 Söllner, Alfred (1987-1995) Justice 4.5 Steiner, Udo \{1995 -- \} Justice 5.1 Zweigert, Konrad (1951-1956) Justice (Seat abolished in 1956) 6.1 Lehmann, Joachim (1951-1963) Justice (Seat abolished in 1963) II. Elected by Bundesrat 1.1 Stein, Erwin (1951-1971) Justice 1.2 Faller, Hans (1971-1983) Justice 1.3 Henschel, Johann (1983-1995) Justice 1.4 Hömig, Dieter \{1995 -- $\} 2.1$ Wessel, Franz (1951-1958) Justice 2.2 Berger, Hugo (1959-1967) Justice 2.3 Zeidler, Wolfgang (1967-1970) Justice 2.4 Simon, Helmut (1970-1987) Justice 2.5 Dieterich, Thomas (1987-1994) Justice 2.6 Jaeger, Renate \{1994 -- 3.1 Scheffler, Erna (1951-1963) Justice 3.2 Rupp-v. Brünneck, Wiltraut (1963-1977) Justice 3.3 Niemeyer, Gisela (19771989) Justice 3.4 Seibert, Helga (1989-1999) Justice 3.5 Hohmann-Dennhard, Christine \{1999 -- $\} 4.1$ Rittersprach, Theodor (1951-1975) Justice 4.2 Hesse, Konrad (1975-1987) Justice 4.3 Grimm, Dieter (1987-1999) Justice 4.4 Hoffman-Riem, Wolfgang \{1999 -- \} Justice 5.1 Ellinghaus, Wilhelm (1951-1955) Justice 5.2 Kutscher, Hans (19551956) Justice (Seat abolished in 1956) 6.1 Drath, Martin (1951-1963) Justice (Seat abolished in 1963) Second Senate I. Elected by the Bundestag's Judicial Selection Committee 1.1 Rupp, Hans (1951-1975) Justice 1.2 Zeidler, Wolfgang (1975-1983) Vice President (1983-1987) President 1.3 Franßen, Everhardt (1987-1991) Justice 1.4 Sommer, Bertold \{1991 -- $\} 2.1$ Hennecka, Anton (1951-1968) Justice 2.2 Rinck, Hans-Justus (1968-1986) Justice 2.3 Graßhof, Karin (1986-1998) Justice 2.4 Osterloh, Lerke \{1998 -- $\}$ Justice 3.1 Federer, Julius (1951-1967) Justice 3.2 von Schlabrendorff, Fabian (1967-1975) Justice 3.3 Niebler, Engelbert (1975-1987) Justice 3.4 Kruis, Konrad (19871998) Justice 3.5 Broß, Siegfried \{1998 -- $\}$ Justice 4.1 Leibholz, Gerhard (1951-1971) Justice 4.2 Hirsch, Martin (1971-1981) Justice 4.3 Mahrenholz, Ernst-Gottfried (1981-1987) Justice (1987-1994) Vice President 4.4 Limbach, Jutta (1994) Vice President $\{1994$-- $\}$ President 5.1 Roediger, Conrad Frederick (1951-1956) Justice (Seat abolished in 1956) 6.1 Klass, Walter (1951-1963) Justice (Seat abolished in 1963) II. Elected by the Bundesrat 1.1 Katz, Rudolf (1951-1961) Vice President 1.2 Wagner, Friedrich (1961-1967) Vice President 1.3 Seuffert, Walter (1967-1975) Vice President 1.4 Steinberger, Helmut (1975-1987) Justice 1.5 Kirchhof, Paul (1987-1999) Justice 1.6 Di Fabio, Udo $\{1999$-- $\}$ Justice 2.1 Geiger, Willi (1951-1977) Justice 2.2 Träger, Ernst (1977-1989) Justice 2.3 Winter, Klaus (19892001) Justice 2.4 Mellinghoff, Rudolf \{2001 -- $\}$ Justice 3.1 Fröhlich, Georg (1951-1956) Justice 3.2 Kutscher, Hans (1956-1970) Justice 3.3 Wand, Walter Rudi (1970-1983) Justice 3.4 Klein, Hans Hugo (1983-1995) Justice 3.5 Jentsch, Hans-Joachim \{1996 -- \} Justice 4.1 Leussner, Carl (1951-1952) Justice 4.2 Schunck, Egon (1952-1963) Justice 4.3 Geller, Gregor (1963-1971) Justice 4.4 Rottmann, Joachim (1971-1983) Justice 4.5 Böckenförde, ErnstWolfgang (1983-1995) Justice 4.6 Hassemer, Winfried \{1996 -- $\}$ Justice 5.1 Wolff, Bernhard (1951-1956) Justice (Seat abolished in 1956) 6.1 Friesenhahn, Ernst (1954-1963) Justice (Seat abolished in 1963)

(1) G. HARUTYUNYAN, A. MAVÈIĖ, CONSTITUTIONAL REVIEW AND ITS DEVELOPMENT IN THE MODERN WORLD (A COMPARATIVE CONSTITUTIONAL ANALYSIS) 16 (1999).

(2) A recent survey identifies the following nations as employing "The 'Austrian' Model" of constitutional review: (Europe) Albania, Andorra, Armenia, Azerbaijan, Austria, Belarus, Belgium, the Bosnian/Herzegovina Federation, Bulgaria, Croatia, the Czech Republic, the Former Republic of Yugoslavia, Georgia, Germany, Hungary, Iceland, Italy, Latvia, Lichtenstein, Lithuania, Luxembourg, Macedonia, Malta, Moldova, Monaco, Poland, Romania, the Russian Federation, Slovakia, Slovenia, Spain, Turkey, Ukraine; (Africa) Angola, Benin, Burkina Faso, Burundi, Cameroon, the Central African Republic, Chad, Egypt, Equatorial Guinea, Eritrea, Gabon, Madagascar, Mali, Niger, Rwanda, South Africa, Sudan, Togo, Uganda, Zaire, Zambia; (Middle East) Cyprus, Palestine, Syria, Yemen; (Asia) Kyrgyzstan, Mongolia, South Korea, Sri Lanka, Tajikistan, Thailand, Uzbekistan; (Central/South America) Chile, Surinam. G. HARUTYUNYAN, A. MAVĖIĖ, CONSTITUTIONAL REVIEW AND ITS DEVELOPMENT IN THE MODERN WORLD (A COMPARATIVE CONSTITUTIONAL ANALYSIS) 30-32 (1999).

(3) Justice Wolfgang Zeidler, Public Address; cited in Kommers, p. 14, note 60; the current President of the Court, Justice, Professor Jutta Limbach, recently remarked: "Using a constitutional complaint, anyone claiming to have gad a fundamental right infringed by an act of the authorities may seek protection from the Federal Constitutional Court . . . this right of appeal [has a] . . . paradigmatic effect on the decisions that is important for the future conduct of politicians, officials, and judges." Jutta Limbach, The Role of the Federal Constitutional Court, 53 SMU L. REV. 429 (2000).

(4) Luise Barnstedt, Administration of the Federal Constitutional Court, Conference of Secretaries General of Constitutional Courts and bodies of equivalent jurisdiction

(5) Article 3: At least 40 years of age, eligible for election to the Bundestag and qualified to exercise the functions of a judge. 
(6) Article 4: 12 years, not to exceed the age of mandatory retirement.

(7) Articles 5-9: Half of each panel is elected by the Bundestag and half by the Bundesrat.

(8) Article 2.

(9) Article 14

(10) The years in $\{x\}$ represent the terms for which currently sitting justices were elected. 